Research Article

\title{
Does Intellectual Capital Investment Improve Financial Competitiveness and Green Innovation Performance? Evidence from Renewable Energy Companies in China
}

\author{
Shuang Liu (D), Qi Yu (D), Liang Zhang $(D$, Jian Xu (D), and Zhenji Jin \\ School of Management, Qingdao Agricultural University, Qingdao 266109, China \\ Correspondence should be addressed to Jian Xu; xujiansword@163.com and Zhenji Jin; zhenji12@aliyun.com
}

Received 2 April 2021; Revised 20 April 2021; Accepted 20 April 2021; Published 26 April 2021

Academic Editor: Mohammad Yazdi

Copyright (c) 2021 Shuang Liu et al. This is an open access article distributed under the Creative Commons Attribution License, which permits unrestricted use, distribution, and reproduction in any medium, provided the original work is properly cited.

\begin{abstract}
This paper aims to investigate the impact of intellectual capital (IC) and its components on financial competitiveness and green innovation performance. The data are collected from renewable energy companies listed on the Shanghai and Shenzhen stock exchanges during 2013-2018. The modified Value Added Intellectual Coefficient (MVAIC) model is applied as a proxy for IC efficiency, an index system is constructed to systematically measure financial competitiveness, and green innovation performance is measured by the total number of green patents, the number of green invention patents, and the number of green noninvention patents. The empirical results show that IC has an inverted U-shaped relationship with financial competitiveness and no impact on green innovation performance. Regarding IC components, human capital (HC), structural capital, and relational capital positively affect financial competitiveness. HC has a negative impact on green patents, while innovation capital has a positive impact on green invention patents. Physical capital is the main driving force of green innovation performance. This study will help managers to reasonably manage their IC resources to strengthen financial competitiveness and achieve green development.
\end{abstract}

\section{Introduction}

In the knowledge era, intellectual capital (IC) is reckoned as the primary source of competitive advantage and financial sustainability, which has drawn the attention of many researchers [1-5]. It is the sum of intangible resources possessed by an organization to generate value [6]. However, traditional accounting fails to reflect the value created by intangibles in companies.

Financial competitiveness is strategic oriented to achieve sustainable competitive advantage and integrate the existing financial elements of companies $[7,8]$. In order to survive in today's globalized economic environment, firms are required to improve their competitiveness. The current research on financial competitiveness is still scarce.

In recent years, the supply of traditional energy has greatly declined. China, a global leader in the renewable energy sector, is continuously increasing the utilization ratio of renewable energy with the support of a series of policies [9]. In line with the goal of building a beautiful China, renewable energy has become the mainstay of national energy strategy. Compared with developed countries, China's renewable energy industry is still in the initial stage of development. Renewable energy is a knowledge- and technology-intensive industry, and the effective utilization of IC is particularly important. Green innovation requires enterprises to carry out technological innovation activities under strict environmental constraints. Additionally, green innovation in the renewable energy sector can reduce greenhouse gas emissions and the cost of renewable energy, achieve economic development, and create a sustainable society [10-12].

Most of the existing studies on IC have been restricted to a certain knowledge-intensive sector such as manufacturing, pharmaceuticals, and banking, and little has been done in the renewable energy sector. The primary objective of this 
paper is to explore the impact of IC and its components on financial competitiveness and green innovation performance. We choose renewable energy companies listed on the Shanghai and Shenzhen stock exchanges from 2013 to 2018 as the research sample. The modified Value Added Intellectual Coefficient (MVAIC) model is used as the measurement of IC, and an index system is set up for analyzing financial competitiveness. Green innovation performance is measured in three aspects: green patents, green invention patents, and green noninvention patents.

This paper contributes to the existing literature in four aspects. First, it expands the current IC literature by examining its impact in the renewable energy sector that attracts relatively little attention. Second, it is the first study to investigate the relationship between IC and financial competitiveness. As financial competitiveness is influenced by many variables, defining it is still a research problem. This paper attempts to construct a financial competitiveness index that can measure a company's competitive position. Third, little has been done on the impact of IC on green innovation performance, and this paper attempts to fill this gap. Finally, the results of this paper would help managers to improve the competitive performance of the firms via effective utilization of their IC resources.

The paper is structured as follows: Section 2 provides the literature review and develops the testable hypotheses, followed by Section 3 describing the research methodology. Section 4 presents and discusses the empirical results. Finally, conclusions are made in Section 5.

\section{Literature Review and Hypotheses Development}

2.1. IC Definition and Measurement. IC, an important intangible asset and strategic resource, is utilized by the organization to create value by transforming it into intellectual property. IC was initially defined as the set of knowledge possessed by the employees as well as the companies [13]. The difference between the market and book value of a firm is also considered as IC [14].

Various typologies of IC have been proposed in the extant research. It is generally believed that IC can be divided into human, structural, and relational capitals [4, 15-27]. Human capital (HC), the most important element of IC, consists of the knowledge, experience, commitment, and motivation of an organization's employees [28]. Structural capital (SC) relates to organizational infrastructure, production processes, operating system, production techniques, organizational culture, and intellectual property [29]. SC can provide a guarantee for HC practices [14]. Relational capital (RC) includes a formal and informal relationship with customers, competitors, and suppliers [30]. In addition, some scholars [2, 31-35] argued that innovation capital (INC) is also an important element of IC that drives wealth creation and superior performance.

There are various methods developed to measure IC, such as the Skandia Navigator, the Intangible Assets Monitor, the balanced scorecard approach, market capitalization methods, and the Value Added Intellectual
Coefficient (VAIC). Among them, the VAIC model proposed by Pulic [36] is universally accepted and utilized in the current IC research. It provides a standardized and consistent basis of measure that allows comparison across organizations, industries, and countries [37]. Another merit is that the easy and simple calculation of VAIC is based on audited financial statements that are reliable and verifiable [36]. Conversely, this method has also received some criticism. First, the model depends on historical data from annual financial reports and thus might not be an appropriate tool for evaluating firms' future value-creating potential. Second, the measure for SC might not be complete by ignoring the important role of RC and INC. Chen et al. [31] argued that RC and INC can build brand value and improve the technological progress of a company.

2.2. Financial Competitiveness. Financial competitiveness is an extension of the theory of corporate core competitiveness from a financial point of view [7]. It refers to a kind of competitiveness that is based on knowledge and innovation and integrates the ability of financial capability to obtain sustainable competitive advantage [38]. Buckley et al. [39] pointed out that competitiveness is related to a firm's longterm financial performance to compensate employees and generate attractive returns for shareholders. Porter [40] defined competitiveness as the firm's ability to successfully compete in a given business environment. Based on factor analysis and fuzzy comprehensive evaluation method, He et al. [41] focused on profitability, solvency, assets management capability, growth ability, and cash support capability to evaluate financial competitiveness of top 20 telecom enterprises chosen from Fortune 500 companies. Ran and Zhang [42] developed an integrated index competitiveness evaluation system that covers three different aspects-profitability capability, debt paying capability, and operation capability. Crowder and Reganold [43] evaluated the financial competitiveness of organic agriculture in terms of costs, gross returns, benefit/cost ratios, net present values, and premiums. Luo [44] used factor analysis with 14 indicators to assess the financial competitiveness of China's agricultural listed companies in three areas of financial viability, financial development, and financial potential. Vijayakumar [45] applied factor analysis to examine the financial competitiveness of 20 Indian automobile companies from 10 aspects: profitability, asset utilization, costeffectiveness, liquidity, working capital efficiency, solvency, market value, foreign trade, productivity, and value added performance. Based on factor analysis, Zhu et al. [38] measured financial competitiveness with 13 indicators such as solvency, development capability, operational capability, profitability, and cash flow ability.

2.3. IC and Financial Performance. A large body of literature has proved a positive relationship between IC and firms' financial performance, and little has been done on the ICfinancial competitiveness relationship. For example, Sardo and Serrasqueiro [46] argued that IC efficiency of the current 
period positively affects the financial performance of listed firms in 14 Western European countries. Xu and Wang [47], using the VAIC model, concluded that the aggregate IC improves the financial performance of publicly traded agribusinesses in China with a lagged effect. Taking manufacturing and service firms listed in Tanzania as the sample, Kasoga [48] discovered that IC is significantly positively related to financial performance measured by return on assets (ROA), asset turnover ratio (ATO), sales growth, and market value.

In terms of IC components, an early study conducted by Ahangar [49] revealed that HC is more efficient than SC and physical capital in financial performance improvement. Based on the model of VAIC, Chowdhury et al. [50] found that SC has an effect on ROA and ATO while HC has an insignificant impact in the Bangladeshi textile sector. Using the same model, Poh et al. [51] pointed out that physical assets have a significant relationship with ROA while $\mathrm{HC}$ and SC have a significant relationship with return on equity (ROE). Mohammad and Bujang [52] documented a positive relationship between $\mathrm{HC}$ and SC and financial performance in the finance sector while documenting a negative relationship between them in the construction and plantain sector. $\mathrm{Xu}$ and $\mathrm{Li}$ [24] found that HC and SC are the main drivers for increasing the performance of China's small- and medium-sized enterprises (SMEs) while RC does not play an important role. Bansal and Singh [53] analyzed the IC performance of software companies in India and found that an increase in SC will lead to the generation of more profit than $\mathrm{HC}$ and physical capital. The findings of Zhu et al. [38] showed that R\&D investment is positively related to the financial competitiveness of China's new energy listed firms. Hence, we formulate the following set of hypotheses:

Hypothesis 1 (H1): there is a positive relationship between IC and financial competitiveness

Hypothesis 1a (H1a): there is a positive relationship between $\mathrm{HC}$ and financial competitiveness

Hypothesis $1 \mathrm{~b}(\mathrm{H} 1 \mathrm{~b})$ : there is a positive relationship between SC and financial competitiveness

Hypothesis 1c (H1c): there is a positive relationship between RC and financial competitiveness

Hypothesis 1d (H1d): there is a positive relationship between INC and financial competitiveness

2.4. IC and Green Innovation Performance. The research on IC and green innovation performance is very scarce. Januškaite and Užienè [54] found that IC is of great importance for sustainable regional economic, environmental, and social sustainability. Green innovation and green production can alleviate the pressure of resources in developing countries, which is the cornerstone of enterprise growth. In terms of HC, Bassi and Buren [55] believed that HC has a positive impact on the competitive advantage of enterprises. Employees' awareness and knowledge of environmental protection might lead to corporate green production [56]. With regard to environmental issues, enterprises abide by environmental rules, establish a green management system, green corporate culture, and green database, and integrate green concepts into each management system, which can enable them to apply for more green patents and bring differentiated competitive advantages [57]. Garcés-Ayerbe et al. [58] found that enterprises are facing more and more environmental pressure from the perspective of stakeholders. Under such circumstances, enterprises hope to establish long-term cooperation with suppliers that provide green raw materials and intermediate products, which in turn improve green innovation performance by providing customers with green products and services. Fu et al. [59] pointed out that regional innovation capability can promote the improvement of green technology manufacturing efficiency in China. Based on the data from Chinese listed firms, $\mathrm{Xu}$ et al. [60] found that R\&D investment has a positive impact on green innovation performance. Hence, we formulate the following set of hypotheses:

Hypothesis $2(\mathrm{H} 2)$ : there is a positive relationship between IC and green innovation performance

Hypothesis 2a ( $\mathrm{H} 2 \mathrm{a})$ : there is a positive relationship between $\mathrm{HC}$ and green innovation performance

Hypothesis $2 \mathrm{~b}(\mathrm{H} 2 \mathrm{~b})$ : there is a positive relationship between SC and green innovation performance

Hypothesis 2c $(\mathrm{H} 2 \mathrm{c})$ : there is a positive relationship between RC and green innovation performance

Hypothesis $2 \mathrm{~d}(\mathrm{H} 2 \mathrm{~d})$ : there is a positive relationship between INC and green innovation performance

\section{Method}

3.1. Sample Selection. The sample consists of renewable energy companies listed on the Shanghai and Shenzhen stocks exchange over a six-year period (2013-2018). Companies with missing information, companies with a debt ratio greater than 1, and special treatment (ST) companies are excluded from the original sample. Finally, we obtain 176 companies with 934 observations. Financial data are retrieved from the China Stock Market \& Accounting Research (CSMAR) database, and green patent information is sourced from China's State Intellectual Property Office.

\subsection{Variables}

(1) Dependent variables: the financial competitiveness index of renewable energy companies is constructed on the basis of five aspects, namely, solvency, development capability, operating capability, profitability, and cash flow ability. Thirteen ratios used in factor analysis are presented in Table 1.

Referring to Xu et al. [60] and Liao [61], green innovation performance (GPATENT) is measured by the total number of green patents (GP) including green invention and noninvention patents, the number of green invention patents (GIP), and the number of green noninvention patents (GNIP). 
TABLE 1: Financial competitiveness evaluation index system.

\begin{tabular}{|c|c|c|}
\hline Variable & Symbol & Description \\
\hline Solvency & $\begin{array}{l}\text { Current ratio (Y1) } \\
\text { Quick ratio (Y2) } \\
\text { Cash ratio (Y3) }\end{array}$ & $\begin{array}{c}\text { Current assets/current liabilities } \\
\text { (Current assets - inventory)/current liabilities } \\
\text { Cash and cash equivalents/current liabilities }\end{array}$ \\
\hline $\begin{array}{l}\text { Development } \\
\text { capability }\end{array}$ & $\begin{array}{l}\text { Growth rate of return on equity (Y4) } \\
\text { Net profit growth rate (Y5) }\end{array}$ & $\begin{array}{l}\text { (Current year's return on equity - last year's return on } \\
\text { equity) }-1 \\
\text { (Current year's net profit - last year's net profit) }-1\end{array}$ \\
\hline Operating capability & $\begin{array}{l}\text { Total assets turnover (Y6) } \\
\text { Current assets turnover (Y7) }\end{array}$ & $\begin{array}{l}\text { Net sales/total assets } \\
\text { Net sales/current assets }\end{array}$ \\
\hline Profitability & $\begin{array}{c}\text { Asset profit ratio (Y8) } \\
\text { Ratio of profits to cost (Y9) } \\
\text { Return on assets (Y10) } \\
\text { Earnings before interest and tax (Y11) }\end{array}$ & $\begin{array}{c}\text { Net profit/total assets } \\
\text { Total profits/(operating costs + total expenses) } \\
\text { (Total profits }+ \text { financial expenses)/average total assets } \\
\text { Earnings before interest and tax/total sales }\end{array}$ \\
\hline Cash flow ability & $\begin{array}{l}\text { Operating cash flows to current liabilities ratio } \\
\text { (Y12) } \\
\text { Operating cash flows to total liabilities ratio (Y13) }\end{array}$ & $\begin{array}{l}\text { Net cash flow from operating activities/current liabilities } \\
\text { Net cash flow from operating activities/total liabilities }\end{array}$ \\
\hline
\end{tabular}

(2) Independent variables: guided by Tripathy et al. [32], $\mathrm{Xu}$ and Liu [34], and Singla [62], the MVAIC model with the introduction of RC and INC is applied to measure IC efficiency. It is based on value added (VA) generated by resources that a company possesses. VA is calculated as the difference between total sales and total expenses excluding employee expenditures. MVAIC is the summation of capital employed efficiency (CEE), human capital efficiency (HCE), structural capital efficiency (SCE), relational capital efficiency (RCE), and innovation capital efficiency (INCE). Their calculations are listed in Table 2.

(3) Control variables: guided by Xu et al. [3, 63], Xu and Liu [5, 34], Buallay et al. [20], $\mathrm{Xu}$ and $\mathrm{Li}[27]$, and $\mathrm{Xu}$ and Wang [47], firm size (SIZE), debt ratio (LEV), and gross domestic product growth rate (GDP) are chosen as control variables. In addition, a year dummy (YEAR) is also included in the regression model.

Table 2 presents the definition of all variables used in the current study.

3.3. Models. Models (1) and (2) are used to examine the impact of IC and its components on financial competitiveness:

$$
\begin{aligned}
\mathrm{FC}_{i, t}= & \beta_{0}+\beta_{1} \mathrm{MVAIC}_{i, t}+\beta_{2} \mathrm{SIZE}_{i, t} \\
& +\beta_{3} \mathrm{LEV}_{i, t}+\beta_{4} \mathrm{GDP}_{i, t}+\Sigma \mathrm{YEAR}+\varepsilon_{i, t} \\
\mathrm{FC}_{i, t}= & \beta_{0}+\beta_{1} \mathrm{CEE}_{i, t}+\beta_{2} \mathrm{HCE}_{i, t} \\
& +\beta_{3} \mathrm{SCE}_{i, t}+\beta_{4} \mathrm{RCE}_{i, t}+\beta_{5} \mathrm{INCE}_{i, t} \\
& +\beta_{6} \mathrm{SIZE}_{i, t}+\beta_{7} \mathrm{LEV}_{i, t}+\beta_{8} \mathrm{GDP}_{i, t}+\Sigma \mathrm{YEAR}+\varepsilon_{i, t} .
\end{aligned}
$$

Models (3) and (4) are applied to examine the impact of IC and its components on the green innovation performance of the selected sample:

$$
\begin{aligned}
\text { GPATENT }_{i, t}= & \beta_{0}+\beta_{1} \mathrm{MVAIC}_{i, t}+\beta_{2} \mathrm{SIZE}_{i, t}+\beta_{3} \mathrm{LEV}_{i, t} \\
& +\beta_{4} \mathrm{GDP}_{i, t}+\Sigma \mathrm{YEAR}+\varepsilon_{i, t}, \\
\text { GPATENT }_{i, t}= & \beta_{0}+\beta_{1} \mathrm{CEE}_{i, t}+\beta_{2} \mathrm{HCE}_{i, t}+\beta_{3} \mathrm{SCE}_{i, t} \\
& +\beta_{4} \mathrm{RCE}_{i, t}+\beta_{5} \mathrm{INCE}_{i, t}+\beta_{6} \mathrm{SIZE}_{i, t} \\
& +\beta_{7} \mathrm{LEV}_{i, t}+\beta_{8} \mathrm{GDP}_{i, t}+\Sigma \mathrm{YEAR}+\varepsilon_{i, t} .
\end{aligned}
$$

where $i$ and $t$ represent the firm and year, respectively; $\beta$ stands for the presumed parameters; and $\varepsilon$ denotes the measurement error term.

\section{Results and Discussion}

4.1. Factor Analysis. Table 3 shows that the KMO value is 0.684 , which is midiocre but still satisfactory. Bartlett's test is significant $(p<0.05)$, which suggests that all variables are uncorrelated.

Table 4 lists the eigenvalues associated with each factor before extraction, after extraction, and after rotation. The results before extraction are shown in the columns labeled initial eigenvalues. The second set of columns, labeled extraction sums of squared loadings, contains the factor solutions after extraction. The third set of columns, labeled rotation sums of squared loadings, display the factors after rotation. Five factors with an eigenvalue greater than 1 account for $84.881 \%$ of the overall variance.

In Table 5, we can see Y8, Y9, Y10, and Y11 load on Factor 1 (profitability); Y1, Y2, and Y3 on Factor 2 (solvency); Y12 and Y13 on Factor 3 (cash flow ability); Y4 and Y5 on Factor 4 (development capability); and the remaining variables on Factor 5 (operating capability). Based on these results, the composite score of firm's financial competitiveness can be expressed as follows: 
TABLE 2: Variable definition.

\begin{tabular}{lcc}
\hline Variable & Symbol & Description \\
\hline Financial competitiveness & FC & Composite score \\
Green patent & GP & Total number of GIP and GNIP \\
Green invention patent & GIP & Number of green invention patents \\
Green noninvention patent & GNIP & Number of green utility model and industrial design \\
Modified Value Added Intellectual Coefficient & MVAIC & CEE + HCE + SCE + RCE + INCE \\
Capital employed efficiency & CEE & VA/book value of net assets \\
Human capital efficiency & HCE & VA/total employee expenditures \\
Structural capital efficiency & SCE & (VA- total employee expenditures)/VA \\
Relational capital efficiency & RCE & Marketing, selling, and advertising expenses/VA \\
Innovation capital efficiency & INCE & R\&D expenses/VA \\
Firm size & SIZE & Natural logarithm of total assets \\
Debt ratio & LEV & Total liabilities/total assets \\
Gross domestic product growth rate & GDP & Growth rate of gross domestic product \\
Year dummy & YEAR & Dummy variable that takes 1 for the test year, 0 otherwise \\
\hline
\end{tabular}

TABLE 3: KMO and Bartlett tests.

\begin{tabular}{lcc}
\hline KMO test value & & 0.684 \\
\hline & The approximate chi-square & 13338.926 \\
Bartlett test & $\mathrm{df}$ & 78 \\
& Sig. & 0.000 \\
\hline
\end{tabular}

TABle 4: Total variance explained.

\begin{tabular}{|c|c|c|c|c|c|c|c|c|c|}
\hline \multirow{2}{*}{ Component } & \multicolumn{3}{|c|}{ Initial eigenvalue } & \multicolumn{3}{|c|}{ Extraction sums of squared loadings } & \multicolumn{3}{|c|}{ Rotation sums of squared loadings } \\
\hline & Total & $\%$ of variance & Cumulative $\%$ & Total & $\%$ of variance & Cumulative \% & Total & $\%$ of variance & Cumulative \% \\
\hline 1 & 4.112 & 31.631 & 31.631 & 4.112 & 31.631 & 31.631 & 3.162 & 24.321 & 24.321 \\
\hline 2 & 3.065 & 23.579 & 55.210 & 3.065 & 23.579 & 55.210 & 2.908 & 22.368 & 46.689 \\
\hline 3 & 1.627 & 12.519 & 67.729 & 1.627 & 12.519 & 67.729 & 1.938 & 14.909 & 61.598 \\
\hline 4 & 1.207 & 9.281 & 77.010 & 1.207 & 9.281 & 77.010 & 1.519 & 11.687 & 73.285 \\
\hline 5 & 1.023 & 7.871 & 84.881 & 1.023 & 7.871 & 84.881 & 1.507 & 11.596 & 84.881 \\
\hline 6 & 0.701 & 5.391 & 90.272 & - & - & - & - & - & - \\
\hline 7 & 0.504 & 3.875 & 94.147 & - & - & - & - & - & - \\
\hline 8 & 0.371 & 2.851 & 96.998 & - & - & - & - & - & - \\
\hline 9 & 0.145 & 1.117 & 98.114 & - & - & - & - & - & - \\
\hline 10 & 0.130 & 0.997 & 99.112 & - & - & - & - & - & - \\
\hline 11 & 0.094 & 0.719 & 99.831 & - & - & - & - & - & - \\
\hline 12 & 0.016 & 0.121 & 99.952 & - & - & - & - & - & - \\
\hline 13 & 0.006 & 0.048 & 100.000 & - & - & - & - & - & - \\
\hline
\end{tabular}

TABLE 5: Component matrix.

\begin{tabular}{|c|c|c|c|c|c|}
\hline \multirow{2}{*}{ Variable } & \multicolumn{5}{|c|}{ Component } \\
\hline & 1 & 2 & 3 & 4 & 5 \\
\hline Y1 & 0.026 & 0.971 & 0.133 & 0.018 & -0.086 \\
\hline Y2 & 0.031 & 0.972 & 0.165 & 0.013 & -0.069 \\
\hline Y3 & 0.010 & 0.926 & 0.148 & -0.012 & -0.028 \\
\hline Y4 & 0.428 & 0.030 & -0.095 & 0.664 & 0.038 \\
\hline Y5 & 0.031 & -0.014 & 0.075 & 0.827 & -0.036 \\
\hline Y6 & 0.013 & 0.041 & -0.107 & 0.046 & 0.908 \\
\hline Y7 & 0.094 & -0.245 & 0.263 & -0.052 & 0.778 \\
\hline Y8 & 0.832 & 0.079 & 0.133 & 0.430 & 0.142 \\
\hline Y9 & 0.918 & 0.052 & 0.174 & 0.136 & -0.051 \\
\hline Y10 & 0.831 & -0.019 & 0.192 & 0.388 & 0.181 \\
\hline Y11 & 0.834 & -0.019 & 0.008 & -0.182 & -0.024 \\
\hline Y12 & 0.173 & 0.202 & 0.932 & 0.000 & 0.033 \\
\hline Y13 & 0.126 & 0.221 & 0.907 & 0.046 & 0.066 \\
\hline
\end{tabular}


TABLe 6: Descriptive statistics.

\begin{tabular}{|c|c|c|c|c|c|}
\hline Variable & $\mathrm{N}$ & Mean & Max & Min & SD \\
\hline FC & 934 & 0.3726 & 8.6772 & -19.2801 & 1.2826 \\
\hline GP & 934 & 2.28 & 90 & 0 & 6.8048 \\
\hline GIP & 934 & 0.73 & 39 & 0 & 3.2064 \\
\hline GNIP & 934 & 1.55 & 58 & 0 & 4.7281 \\
\hline MVAIC & 934 & 5.2433 & 39.6007 & -1.3193 & 2.5121 \\
\hline CEE & 934 & 0.3279 & 2.2902 & -0.0589 & 0.1929 \\
\hline $\mathrm{HCE}$ & 934 & 4.0095 & 38.3861 & -0.4114 & 2.4402 \\
\hline SCE & 934 & 0.6916 & 3.4309 & -1.7424 & 0.1917 \\
\hline $\mathrm{RCE}$ & 934 & 0.1174 & 0.8966 & -2.1526 & 0.1222 \\
\hline INCE & 934 & 0.0969 & 0.6722 & -1.1049 & 0.0888 \\
\hline SIZE & 934 & 22.6301 & 27.2931 & 19.0072 & 1.3425 \\
\hline LEV & 934 & 0.4824 & 0.9085 & 0.0398 & 0.1915 \\
\hline GDP & 934 & 0.070 & 0.078 & 0.066 & 0.0040 \\
\hline
\end{tabular}

$$
\mathrm{FC}=\frac{(24.321 \times \text { Factor } 1+22.368 \times \text { Factor } 2+14.909 \times \text { Factor } 3+11.687 \times \text { Factor } 4+11.596 \times \text { Factor } 5)}{84.881} .
$$

4.2. Descriptive Statistics. Descriptive statistics of all variables are shown in Table 6. FC has a mean value of 0.3276 , indicating that the financial competitiveness of China's renewable energy companies is relatively weak. The mean values of GP, GIP, and GNIP are 2.28, 0.073, and 1.55, respectively, which suggests that these companies do not pay enough attention to clean production and green development. MVAIC has a mean value of 5.2433, suggesting that renewable energy companies can generate an average value of 5.2433 for one monetary unit invested. Firms operating in the energy sector are found to have better IC performance [61]. HCE is a major component of MVAIC with a mean value of 4.0095 , which indicates the cruciality of $\mathrm{HC}$ in value generation. This finding is in line with most previous studies $[2,3,5,16,24-27,32,34,47,50,64]$. The sum of the mean value of HCE, SCE, RCE, and INCE (4.9154) is much higher than the mean value of CEE (0.3279), implying that intangibles are of greater importance than tangibles in firms' value creation. It is worth noticing that INCE has the lowest mean value of 0.0969 , which indicates that $R \& D$ investment in renewable energy companies is not sufficient. In addition, the mean values of SIZE and LEV are 22.6301 and 0.4824 , respectively.

4.3. Correlation Analysis. Table 7 shows the results of correlation analysis. FC is positively correlated with MVAIC, HCE, SCE, and INCE while it is negatively correlated with CEE. GP, GIP, and GNIP are all positively correlated with $\mathrm{CEE}, \mathrm{RCE}$, and INCE. All values of variance inflation factor (VIF) are calculated to be less than 5, suggesting that multicollinearity is not a major issue in this study.

\subsection{Regression Results}

4.4.1. IC and Financial Competitiveness. Table 8 shows the regression results of Models (1) and (2). Based on the Hausman specification test [65], the fixed effects (FE) model is used in Models (1) and (2). It is clearly shown in Model (1) that the coefficient of MVAIC is positive and significant $(\beta=0.208, t=7.55)$, supporting H1. Xu and Liu [5] also concluded that IC is positively correlated with economic sustainable performance measured through ROA. In terms of IC components, HC, SC, and RC exert a significantly positive impact on financial competitiveness, which leads to the acceptance of $\mathrm{H} 1 \mathrm{a}, \mathrm{H} 1 \mathrm{~b}$, and $\mathrm{H} 1 \mathrm{c}$. SC is the most influential contributor to the financial competitiveness of renewable energy companies. The coefficient of INCE is positive but not statistically significant at the $5 \%$ level $(\beta=1.522, t=1.47)$. Therefore, H1d is not supported. Huo [66] and Zhang [67] found that the R\&D input performance of China's renewable energy companies is still low. However, Zhu et al. [38] concluded that the current R\&D investment has a significant positive impact on the financial competitiveness of China's new energy companies. It is noticeable that physical capital has no significant impact on financial competitiveness, which proved that the development pattern of companies has changed from the capital-driven to the knowledge-driven. Conversely, $\mathrm{Xu}$ and Liu [5] found that renewable energy companies rely mainly on physical and financial assets from 2010 to 2016. In addition, based on the survey of 50 energy enterprises, Zhang [68] found that $\mathrm{HC}$ management, proprietary knowledge base, $\mathrm{RC}$, and technology capital have the most significant positive effect on enterprise value.

As for control variables, firm size (SIZE) has a positive impact on financial competitiveness while debt ratio (LEV) has a negative impact.

4.4.2. IC and Green Innovation Performance. Table 9 presents the regression results of Models (3) and (4). The probability values of the Hausman test are greater than 0.05 , and the random effects (RE) model is more appropriate to be used in Model (3). In Model (4), the FE model is used with the GP and GNIP variables, while the RE model is used when GIP is the dependent variable. In Model (3), the coefficients of MVAIC are negative but not significant at the $5 \%$ level, rejecting our $\mathrm{H} 2$. In Model (4), CEE exerts a positive impact 


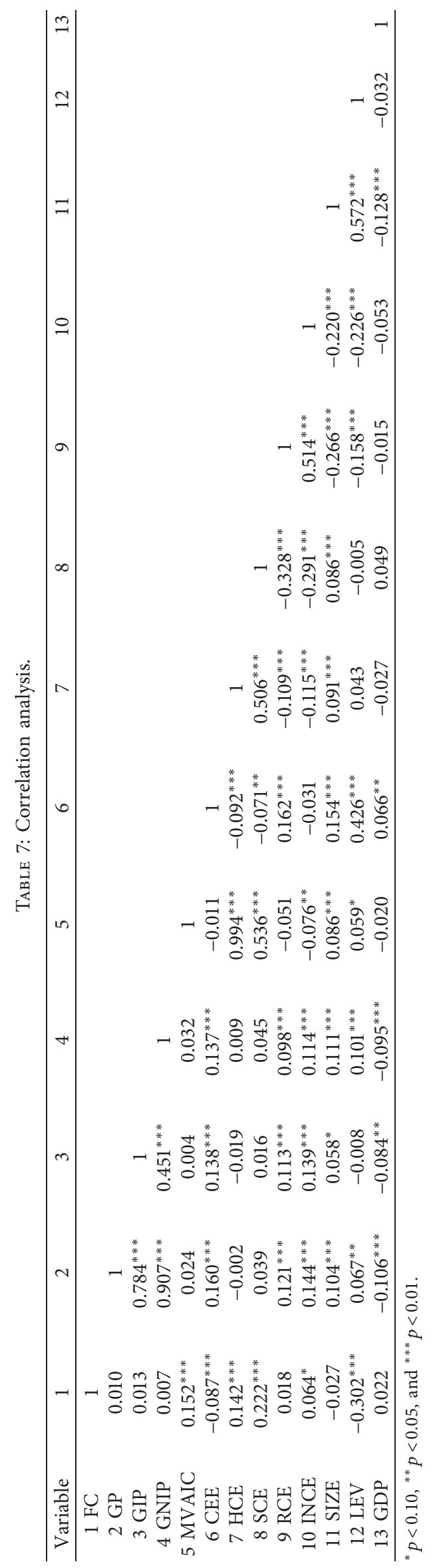




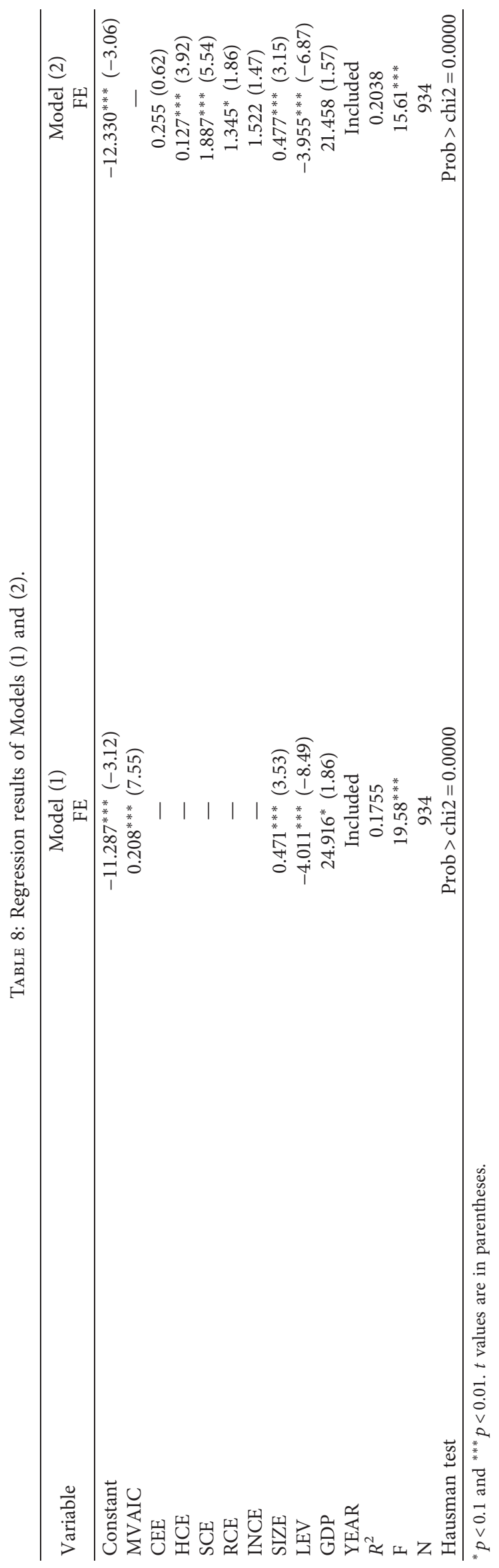




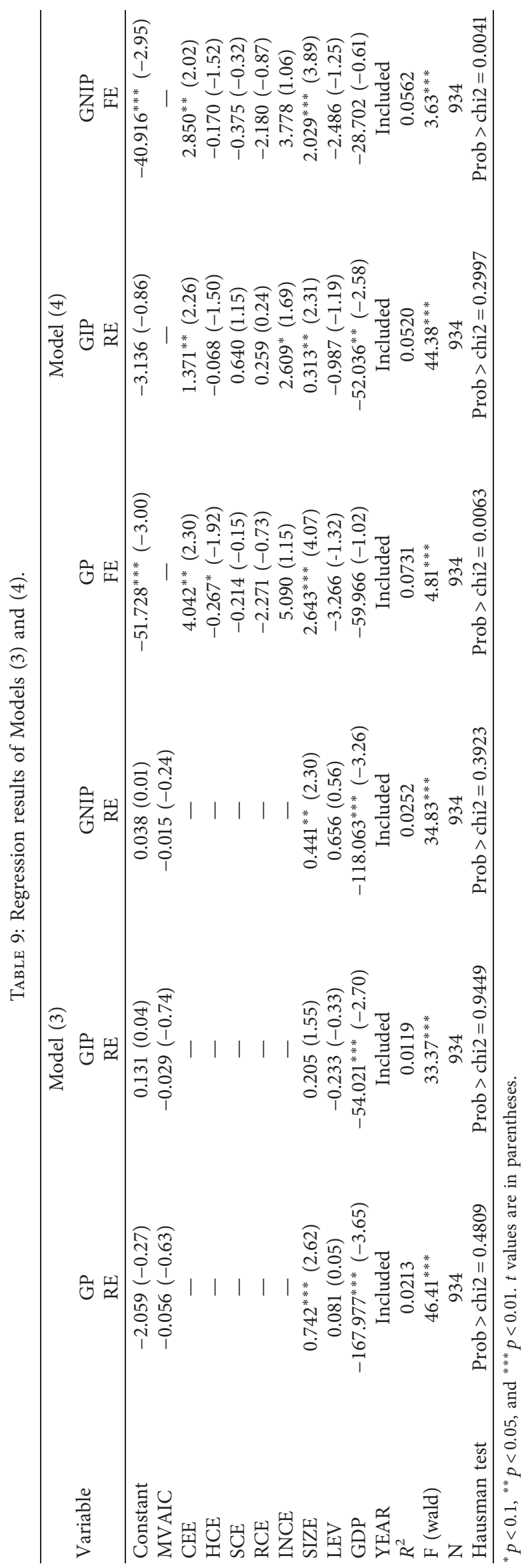


TABLE 10: Regression results of nonlinear relationship.

\begin{tabular}{lcc}
\hline Variable & Coefficient & $t$ value \\
\hline Constant & $-9.860^{* * *}$ & -2.78 \\
MVAIC & $0.522^{* * *}$ & 8.79 \\
MVAIC & $-0.018^{* * *}$ & -5.93 \\
SIZE & $0.384^{* * *}$ & 2.92 \\
LEV & $-3.990^{* * *}$ & -8.64 \\
GDP & 17.740 & 1.35 \\
YEAR & \multicolumn{2}{c}{ Included } \\
$R^{2}$ & 0.2132 \\
F & \multicolumn{2}{c}{$22.12^{* * *}$} \\
N & 934 \\
Hausman test & \multicolumn{2}{c}{ Prob $>$ chi2 $=0.0000$} \\
\hline
\end{tabular}

${ }^{* * *} p<0.01$.

on green innovation performance. $\mathrm{HC}$ is significantly negatively related to only GP, which results in the rejection of $\mathrm{H} 2 \mathrm{a}$. This might be explained by the fact that the accumulation of HC in China's renewable energy companies is relatively weak, especially the lack of professional and technical personnel. Energy companies are losing their knowledge workers with the rising demand in the market [69]. It was reported that it takes a long time for less experienced employees to reach full productivity [69]. Cao et al. [70] argued that HC displays a significant and negative impact on the innovation performance of growth firms in the case of China.

SCE and RCE have no impact on green innovation performance, rejecting $\mathrm{H} 2 \mathrm{~b}$ and $\mathrm{H} 2 \mathrm{c}$. It might be because the database and institutionalized knowledge stored in enterprises are not beneficial to the knowledge transformation, which hinders green innovation performance. There is a significant and positive relationship between INC and GIP. Thus, H2d is partially accepted. Chen and Lin [10] found that $R \& D$ spending is conducive to the patent counts of renewable energy technologies in China.

In addition, for manufacturing listed companies, human, structural, and relational capitals promote enterprise innovation performance [71]. Regarding control variables, SIZE positively influences green innovation performance in China's renewable energy sector.

4.5. Robustness Check. We also use one-year lagged IC and its components and reestimate Models (1)-(4). The results are similar to the findings in Tables 8 and 9. Thus, it can be concluded that our results are robust.

4.6. Additional Analysis. We attempt to explore the nonlinear relationship between IC and financial competitiveness by adding the square of MVAIC in Model (1). The regression results are shown in Table 10, and the FE model is used. The coefficient of MVAIC is positive and statistically significant $(\beta=0.522, t=8.79)$, and the coefficient of MVAIC ${ }^{2}$ is negative and significant $(\beta=-0.018, t=-5.93)$, which suggests an inverted U-shaped relationship between IC and financial competitiveness. This is in line with the findings of Yao et al. [26] and Haris et al. [72].

\section{Conclusions}

The present study analyzes the impact of IC and its components on financial competitiveness and green innovation performance within the Chinese industry of renewable energy. The MVAIC model is adopted for the measurement of IC. An index system is constructed to measure financial competitiveness, and green innovation performance is measured in three aspects: total number of green patents, the number of green invention patents, and the number of green noninvention patents. Correlation analysis and multiple regressions are used to find the relationship between the dependent variables and the independent variables. The main conclusions are summarized as follows:

(1) IC has a nonlinear relationship with financial competitiveness. Specifically, investment in IC resources can stimulate the financial competitiveness of renewable energy companies in China; up to a certain level, it becomes a restrictive determinant hindering financial competitiveness.

(2) Human, structural, and relational capitals exert a positive impact on financial competitiveness, while physical capital and INC have no impact.

(3) IC has no significant impact on green innovation performance. Physical assets enhance green innovation performance. INC has a positive impact on green invention patents, while $\mathrm{HC}$ has a negative impact on the application of green patents.

The theoretical contributions can be discussed in three aspects. First, this paper intends to contribute to the measurement of financial competitiveness by constructing an index system. Second, it is one of the few studies to examine the impact of IC on green innovation performance and extends prior research. Furthermore, it also helps management have a holistic understanding of the important role of IC in the competitive improvement and green development.

Based on the above analysis, this paper puts forward the following practical implications:

(1) Managers in the renewable energy sector should be aware of the importance of IC and strengthen the management of IC. Although physical assets are not beneficial to financial competitiveness, there is no doubt that they positively affect green innovation performance. Therefore, renewable energy companies should take full advantage of their physical capital.

(2) Renewable energy companies should put great emphasis on HC management, improve employees' quality by continuous training, and recruit high-level talents. Meanwhile, they need to construct a perfect employee incentive system and build an innovative work environment to enhance employees' ability of knowledge application.

(3) The insignificant impact of SC on green innovation performance indicates the lack of SC integration within the firm. Renewable energy companies should 
enhance information transmission, construct a standardized production process, and establish an institutionalized management mode for innovation and cooperation. Meanwhile, they should also pay attention to the accumulation of proprietary knowledge base such as the patent right and information system.

(4) Renewable energy companies should not only pay attention to the demand of consumers but also keep close relationships with suppliers, distributors, government, partners, and competitors. They can carry out marketing activities through various social networks to earn more profits.

(5) Managers should foster technological innovation and make continuous investment in $\mathrm{R} \& \mathrm{D}$ activities to improve resource utilization efficiency and implement cleaner production in industrial transformation.

This paper has some limitations. First, it is based on a sample of Chinese renewable energy companies, and the results should be tested in different sectors. Second, some other factors (e.g., corporate governance) should be taken into consideration in future research.

\section{Data Availability}

The data used to support the findings of this study are available from the corresponding author upon request.

\section{Conflicts of Interest}

The authors declare that they have no conflicts of interest.

\section{Acknowledgments}

The research was funded by the Social Science Planning Research Program of Shandong Province (Grant no. 18CKJJ01), the Scientific Research Foundation for HighLevel Talents of Qingdao Agricultural University (Grant no. 6631120701), and the Postgraduate Innovation Program of Qingdao Agricultural University (Grant no. QNYCX20013).

\section{References}

[1] S. Cabrilo, T. Savic-Sikoparija, D. Hristic, and J. VemicDjurkovic, "Defining indicators of organizational intellectual capital: the study of Serbian mining and energy sector," Metalurgia International, vol. 18, no. 3, pp. 174-180, 2013.

[2] J. Xu and B. Wang, "Intellectual capital, financial performance and companies' sustainable growth: evidence from the Korean manufacturing industry," Sustainability, vol. 10, no. 12, p. 4651, 2018.

[3] J. Xu, M. Haris, and H. X. Yao, "Should listed banks be concerned with intellectual capital in emerging Asian markets? a comparison between China and Pakistan," Sustainability, vol. 11, no. 23, p. 6582, 2019.

[4] J. Xu, Y. Shang, W. Z. Yu, and F. Liu, "Intellectual capital, technological innovation and firm performance: evidence from China's manufacturing sector," Sustainability, vol. 11, no. 19, p. 5328, 2019.
[5] X.-L. Xu and C. K. Liu, "How to keep renewable energy enterprises to reach economic sustainable performance: from the views of intellectual capital and lifecycle," Energy Sustainability and Society, vol. 9, no. 1, p. 7, 2019.

[6] A. Kianto, J. Sáenz, and N. Aramburu, "Knowledge-based human resource management practices, intellectual capital and innovation," Journal of Business Research, vol. 81, pp. 11-20, 2017.

[7] J. Tang and Y. Fu, "Analysis and research on financial competitiveness of listed companies in offshore engineering manufacturing," Journal of Coastal Research, vol. 106, pp. 45-48, 2020.

[8] W. Lv and Z. A. Salam, "Evaluation and research on financial competitiveness of innovation-driven enterprises based on interval data mining," International Journal of Pattern Recognition and Artificial Intelligence, vol. 34, no. 12, Article ID 2059040, 2020.

[9] K. Chang, Q. Wan, Q. Lou, Y. Chen, and W. Wang, "Green fiscal policy and firms' investment efficiency: new insights into firm-level panel data from the renewable energy industry in China," Renewable Energy, vol. 151, pp. 589-597, 2020.

[10] Y. Chen and B. Lin, "Decomposition analysis of patenting in renewable energy technologies: from an extended LMDI approach perspective based on three five-year plan periods in China," Journal of Cleaner Production, vol. 269, Article ID 122402, 2020.

[11] N. Shen, Y. Wang, H. Peng, and Z. Hou, "Renewable energy green innovation, fossil energy consumption, and air pollution-Spatial empirical analysis based on China," Sustainability, vol. 12, no. 16, p. 6397, 2020.

[12] W. Chen, X. F. Wang, N. Peng, X. Wei, and C. R. Lin, "Evaluation of the green innovation efficiency of Chinese industrial enterprises: research based on the three-stage chain network SBM model," Mathematical Problems in Engineering, vol. 2020, Article ID 3143651, 11 pages, 2020.

[13] N. Bontis, "Assessing knowledge assets: a review of the models used to measure intellectual capital," International Journal of Management Reviews, vol. 3, no. 1, pp. 41-60, 2001.

[14] L. Edvinsson and M. S. Malone, Intellectual Capital: Realizing Your Company's True Value by Finding its Hidden Brainpower, Harper Business, New York, NY, USA, 1997.

[15] M. H. F. Zarandi, N. Mohammadhasan, and S. Bastani, "A fuzzy rule-based expert system for evaluating intellectual capital," Advances in Fuzzy Systems, vol. 2012, Article ID 823052, 11 pages, 2012.

[16] S. Nimtrakoon, "The relationship between intellectual capital, firms' market value and financial performance: empirical evidence from the ASEAN," Journal of Intellectual Capital, vol. 16, no. 3, pp. 587-618, 2015.

[17] S. G. Yaseen, D. Dajani, and Y. Hasan, "The impact of intellectual capital on the competitive advantage: applied study in Jordanian telecommunication companies," Computers in Human Behavior, vol. 62, pp. 168-175, 2016.

[18] N. Smriti and N. Das, "Impact of intellectual capital on business performance: evidence from Indian pharmaceutical sector," Polish Journal of Management Studies, vol. 15, no. 1, pp. 232-243, 2017.

[19] F. Sardo, Z. Serrasqueiro, and H. Alves, "On the relationship between intellectual capital and financial performance: a panel data analysis on SME hotels," International Journal of Hospitality Management, vol. 75, pp. 67-74, 2018.

[20] A. Buallay, R. Cummings, and A. Hamdan, "Intellectual capital efficiency and bank's performance: A comparative 
study after the global financial crisis," Pacific Accounting Review, vol. 31, no. 4, pp. 672-694, 2019.

[21] S. Muda and M. R. C. A. Rahman, "Sectoral effects of intellectual capital on Malaysian SME business performance," Asia-Pacific Management Accounting Journal, vol. 14, no. 3, pp. 151-175, 2019.

[22] S. Ulubeyli and D. Yorulmaz, "Intellectual capital based reputation for market internationalization: the case of engineering consultancy firm," Journal of Intellectual Capital, vol. 21, no. 1, pp. 40-61, 2019.

[23] H. Vidyarthi and R. Tiwari, "Cost, revenue, and profit efficiency characteristics, and intellectual capital in Indian banks," Journal of Intellectual Capital, vol. 21, no. 1, pp. 1-22, 2019.

[24] J. Xu and J. Li, "The impact of intellectual capital on SMEs' performance in China: Empirical evidence from non-hightech vs. high-tech SMEs," Journal of Intellectual Capital, vol. 20, no. 4, pp. 488-509, 2019.

[25] J. Xu and B. Wang, "Intellectual capital performance of the textile industry in emerging markets: a comparison with China and South Korea," Sustainability, vol. 11, no. 8, p. 2354, 2019.

[26] H. Yao, M. Haris, G. Tariq, H. M. Javaid, and M. A. S. Khan, "Intellectual capital, profitability, and productivity: evidence from Pakistani financial institutions," Sustainability, vol. 11, no. 14 , p. 3842, 2019.

[27] J. Xu and J. S. Li, "The interrelationship between intellectual capital and firm performance: evidence from China's manufacturing sector," Journal of Intellectual Capital, vol. 22, 2020.

[28] N. Bontis, "Intellectual capital: an exploratory study that develops measures and models," Management Decision, vol. 36, no. 2, pp. 63-76, 1998.

[29] W. H. A. Johnson, "An integrative taxonomy of intellectual capital: measuring the stock and flow of intellectual capital components in the firm," International Journal of Technology Management, vol. 18, pp. 562-575, 1999.

[30] G. Roos and J. Roos, "Measuring your company's intellectual performance," Long Range Planning, vol. 30, no. 3, pp. 413-426, 1997.

[31] M. C. Chen, S. J. Cheng, and Y. Hwang, "An empirical investigation of the relationship between intellectual capital and firms' market value and financial performance," Journal of Intellectual Capital, vol. 6, no. 2, pp. 159-176, 2005.

[32] T. Tripathy, L. A. G. Alana, and D. Sahoo, "The effect of intellectual capital on firms' financial performance: an empirical investigation in India," International Journal of Learning and Intellectual Capital, vol. 12, no. 4, pp. 342-371, 2015.

[33] A. E. Bayraktaroglu, F. Calisir, and M. Baskak, "Intellectual capital and firm performance: an extended VAIC model," Journal of Intellectual Capital, vol. 20, no. 3, pp. 406-425, 2019.

[34] J. Xu and F. Liu, "The impact of intellectual capital on firm performance: a modified and extended VAIC model," Journal of Competitiveness, vol. 12, no. 1, pp. 161-176, 2020.

[35] Y. Z. Lu, Z. R. Tian, G. A. Buitrago, S. W. Gao, Y. J. Zhao, and S. Zhang, "Intellectual capital and firm performance in the context of venture-capital syndication background in China," Complexity, vol. 2021, Article ID 3435725, 17 pages, 2021

[36] A. Pulic, "VAIC ${ }^{\mathrm{TM}}$-an accounting tool for IC management," International Journal of Technology Management, vol. 20, no. 5-8, pp. 702-714, 2020.
[37] S. Firer and S. Mitchell Williams, "Intellectual capital and traditional measures of corporate performance," Journal of Intellectual Capital, vol. 4, no. 3, pp. 348-360, 2003.

[38] Z. Zhu, Z. Zhu, P. Xu, and D. Xue, "Exploring the impact of government subsidy and R\&D investment on financial competitiveness of China's new energy listed companies: an empirical study," Energy Reports, vol. 5, pp. 919-925, 2019.

[39] P. J. Buckley, C. L. Pass, and K. Prescott, "Measures of international competitiveness: a critical survey," Journal of Marketing Management, vol. 4, no. 2, pp. 175-200, 1988.

[40] M. E. Porter, The Competitive Advantage of Nations, Free Press, New York, NY, USA, 1990.

[41] Y. He, J. Dong, and R. H. Bai, "The evaluation model of financial competitiveness in telecom enterprises," Advances in Applied Economics, Business and Development, vol. 209, 2011 https://link.springer.com/chapter/10.1007\%2F978-3-64223020-2_4.

[42] F. Ran and X. L. Zhang, "Financial competitiveness evaluation on sporting goods listed enterprises: a China study," African Journal of Business Management, vol. 5, no. 17, pp. 7404-7409, 2011.

[43] D. W. Crowder and J. P. Reganold, "Financial competitiveness of organic agriculture on a global scale," Proceedings of the National Academy of Sciences, vol. 112, no. 24, pp. 7611-7616, 2015.

[44] X.-T. Luo, "A study on the financial competitiveness of listed companies-taking agricultural listed companies as an example," 2017, http://download.atlantis-press.com/php/ download_paper.php?id=25876866.

[45] A. Vijayakumar, "Financial competitiveness of firms: a study of the Indian automobile industry," SMART Journal of Business Management Studies, vol. 14, no. 1, pp. 91-103, 2018.

[46] F. Sardo and Z. Serrasqueiro, "Intellectual capital, growth opportunities, and financial performance in European firms: dynamic panel data analysis," Journal of Intellectual Capital, vol. 19, no. 4, pp. 747-767, 2018.

[47] J. Xu and B. H. Wang, "Intellectual capital and financial performance of Chinese agricultural listed companies," Custos e Agronegocio On Line, vol. 15, no. 1, pp. 273-290, 2019.

[48] P. S. Kasoga, "Does investing in intellectual capital improve financial performance? panel evidence from firms listed in Tanzania DSE," Cogent Economics \& Finance, vol. 8, no. 1, Article ID 1802815, 2020.

[49] R. G. Ahangar, "The relationship between intellectual capital and financial performance: an empirical investigation in an Iranian company," African Journal of Business Management, vol. 5, no. 1, pp. 88-95, 2011.

[50] L. A. M. Chowdhury, T. Rana, M. Akter, and M. Hoque, "Impact of intellectual capital on financial performance: evidence from the Bangladeshi textile sector," Journal of Accounting \& Organizational Change, vol. 14, no. 4, pp. 429454, 2018

[51] L. T. Poh, A. Kilicman, and S. N. I. Ibrahim, "On intellectual capital and financial performances of banks in Malaysia," Cogent Economics \& Finance, vol. 6, no. 1, Article ID 1453574, 2018.

[52] H. S. Mohammad and I. Bujang, "Does intellectual capital influence firms' financial performance? a comparative analysis into three Malaysian industries," International Journal of Business and Society, vol. 20, no. 1, pp. 260-276, 2019.

[53] D. Bansal and S. Singh, "Impact of intellectual capital on financial performance of the Indian software sector," AsiaPacific Management Accounting Journal, vol. 15, no. 1, pp. 67-95, 2020. 
[54] V. Januškaitė and L. Užienè, "Intellectual capital as a factor of sustainable regional competitiveness," Sustainability, vol. 10, no. 12 , p. $4848,2018$.

[55] L. J. Bassi and M. E. V. Buren, "Valuing investments in intellectual capital," International Journal of Technology Management, vol. 18, pp. 414-432, 1999.

[56] C. L. Pan and H. Tian, "How does green intellectual capital become firm competitive advantages in China's economic new normal stage?" Journal of Shanghai University of Finance and Economics, vol. 18, no. 2, pp. 77-90, 2016, (In Chinese).

[57] C.-L. Pan and H. Tian, "The study of the impact of the proactive environmental strategy on green innovation performance-The chain mediation effect of green intellectual capital and a absorptive capacity," Collected Essays on Finance and Economics, vol. 32, no. 7, pp. 85-93, 2016, (In Chinese).

[58] C. Garcés-Ayerbe, P. Rivera-Torres, and J. L. Murillo-Luna, "Stakeholder pressure and environmental proactivity: moderating effect of competitive advantage expectations," Management Decision, vol. 50, no. 1-2, pp. 189-206, 2012.

[59] Y. Fu, A. Supriyadi, T. Wang, L. Wang, and G. T. Cirella, "Effects of regional innovation capability on the green technology efficiency of China's manufacturing industry: evidence from listed companies," Energies, vol. 13, no. 20, p. 5467, 2020.

[60] J. Xu, F. Liu, and Y. Shang, "R\&D investment, ESG performance and green innovation performance: evidence from China," Kybernetes, vol. 50, no. 3, pp. 737-756, 2020.

[61] Z. Liao, "Is environmental innovation conducive to corporate financing? The moderating role of advertising expenditures," Business Strategy and the Environment, vol. 29, no. 3, pp. 954-961, 2020.

[62] H. K. Singla, "Does VAIC affect the profitability and value of real estate and infrastructure firms in India? A panel data investigation," Journal of Intellectual Capital, vol. 21, no. 3, pp. 309-331, 2020.

[63] X.-L. Xu, X.-N. Yang, L. Zhan, C. K. Liu, N.-D. Zhou, and $\mathrm{M} . \mathrm{Hu}$, "Examining the relationship between intellectual capital and performance of listed environmental protection companies," Environmental Progress \& Sustainable Energy, vol. 36, no. 4, pp. 1056-1066, 2017.

[64] K. Tandon, H. Purohit, and D. Tandon, "Measuring intellectual capital and its impact on financial performance: empirical evidence from CNX nifty companies," Global Business Review, vol. 17, no. 4, pp. 980-997, 2016.

[65] J. A. Hausman, "Specification tests in econometrics," Econometrica, vol. 46, no. 6, pp. 1251-1271, 1978.

[66] Z. F. Huo, "Research on the performance of new energy enterprise technology research and development project based on DEA model," Master's Dissertation, North China Electric Power University, Beijing, China, 2017.

[67] H. X. Zhang, "Research on evaluation of technology innovation efficiency of new energy enterpirses," Master's Dissertation, Xi' an University of Science and Technology, Xi'an, China, 2020.

[68] X. F. Zhang, "The value creation study of intellectual capital for energy science and technology enterprises," Master's Dissertation, Xi'an Shiyou University, Xi'an, China, 2014.

[69] D. A. Buczek, "Combating brain drain: retaining intellectual capital in the energy industry," Journal of Petroleum Technology, vol. 54, no. 1, pp. 26-30, 2002.

[70] Y. Cao, S. Y. Xiong, and H. L. Hu, "A study of the relationship between intellectual capital and innovation performance based on the life cycle of enterprises," Science Research Management, vol. 37, no. 10, pp. 69-78, 2016, (In Chinese).
[71] K. Y. Cui, "A study of the relationship between intellectual capital and enterprise innovation performance," Master's Dissertation, Shandong University, Jinan, China, 2016.

[72] M. Haris, H. Yao, G. Tariq, A. Malik, and H. Javaid, "Intellectual capital performance and profitability of banks: evidence from Pakistan," Journal of Risk and Financial Management, vol. 12, no. 2, p. 56, 2019. 